\title{
埋立護岸背後での越波増大と背後地盤の陥没 一館山湾に面した見物海岸の事例一
}

\author{
西村 和真 ${ }^{1} \cdot$ 小林 昭男 ${ }^{2} \cdot$ 宇多 高明 ${ }^{3} \cdot$ 野志 $\quad$ 保仁 ${ }^{4}$ \\ ${ }^{1}$ 日本大学理工学部海洋建築工学科（干274-8501 千葉県船橋市習志野台 7-24-1) \\ ${ }^{2}$ 正会員 日本大学教授理工学部海洋建築工学科（干274-8501 千葉県船橋市習志野台7-24-1） \\ E-mail: kobayashi.akio@nihon-u.ac.jp \\ ${ }^{3}$ 正会員 一般財団法人土木研究センターなぎさ総合研究所長兼日本大学客員教授理工学部 \\ 海洋建築工学科（干110-0016 東京都台東区台東1-6-4） \\ E-mail: uda@pwrc.or.jp \\ 4正会員 日本大学助教理工学部海洋建築工学科（干274-8501 千葉県船橋市習志野台7-24-1） \\ E-mail: noshi.yasuhito@nihon-u.ac.jp
}

\begin{abstract}
2015年4月18日，館山湾南岸にある見物海岸の刀切神社前面の公園を観察した．この公園は，磯と砂浜 の続く場所が埋め立てられて造成されたもので，直立護岸背後の平坦地が公園となっていた．公園の外郭 をなす護岸付近を観察したところ，護岸前面に岩礁がある場所では背後地は安定であったが，岩礁と岩礁 の間で沖合から護岸前面へと深みが迫る場所では護岸背後への越波が著しく, 背後地では吸出しによる陥 没も起きていた。本研究では，この理由を調べることを目的とし，地形測量や越波の現地観測を行うとと もにVOF法による越波量の計算を行うことにより考察した。
\end{abstract}

Key Words : land reclamation, Kenbutsu coast, Tateyama Bay, wave overtopping, field observation

\section{1. はじめに}

2015年4月18日, 館山湾南岸において洲崎へと続く海岸 線のほぼ中央部に位置する見物海岸の現地踏査を行った。 この踏査では，海岸線近くにある刀切神社の前面におい て埋め立てにより造られた公園を観察した．踏査によれ ば，この公園は元々磯とパッチ状の砂浜からなっていた 場所が埋め立てられて造成されたもので，その外縁は滑 らかな曲線状の護岸で防護されていた。すなおち，この 公園は埋め立てにより海浜地が盛り土され，その海側端 に直立護岸が伸ばされたもので，その背後の平坦地が芝 張りのなされた公園となっていた. しかしながら，公園 の外郭をな寸護岸付近を観察したところ, 護岸前面に岩 礁がある場所では背後地は安定であったが，岩礁と岩礁 の間で沖合から護岸前面へと深みが迫る場所では護岸背 後への越波が著しく, 背後地では吸出しによる陷没も観 察された。 このような状況は, 元々見物海岸での埋立地 造成において護岸前面にある岩礁間の深みの存在と無関 係に埋立法線が定められた結果，岩礁背後では護岸基部 の標高が高くなったのに対し，岩礁間の窪地では地盤高 が低く，このため波の侵入度が高まったためと推察され た.このように, 海岸線付近での埋立地造成では, 海側 の条件が十分考慮されないまま都市計画の立場から土地

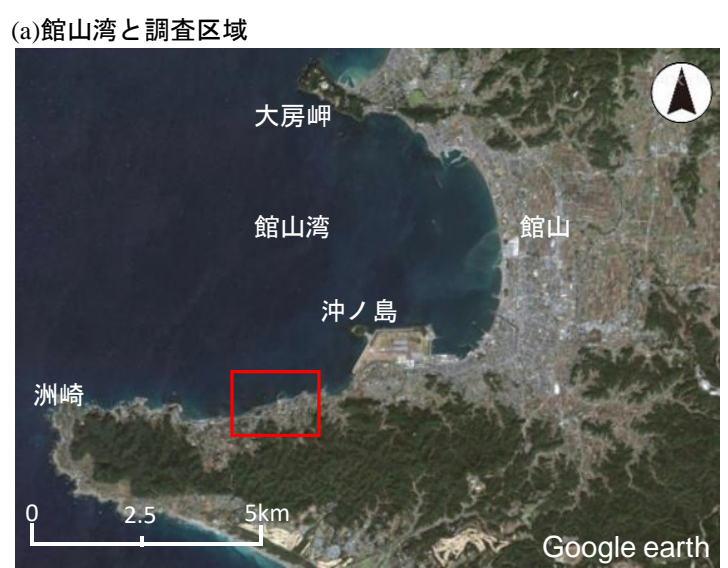

(b)調査区域の拡大衛星画像

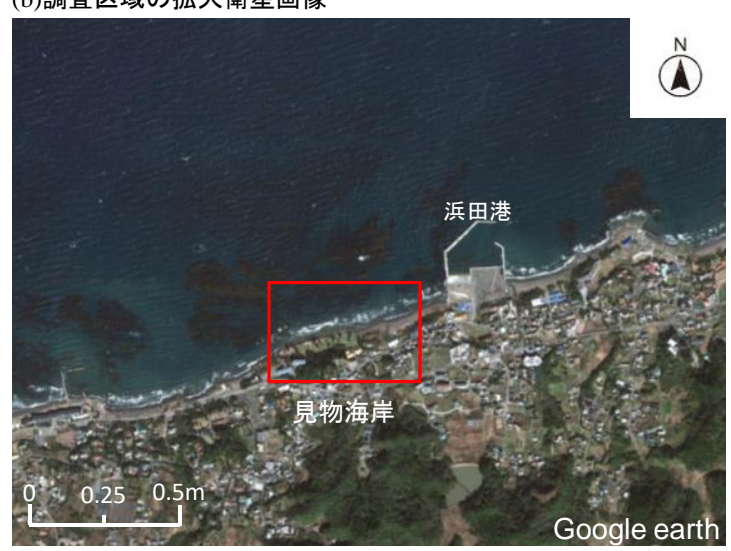

図-1 見物海岸の位置 
の利便性を最大限高めるように埋立地の法線形が定めら れることが問題の発端となり，そのことが後に背後地の 維持管理に課題を残し，新たな消波対策が求められる要 因となる．この種の実例は全国的に多く見られる．そこ で本研究では，見物海岸を研究対象として地形測量や越 波観測とともに，VOF法による越波計算によりこの種の 課題について考察した.

\section{2. 見物海岸の地形的特徵}

見物海岸は，房総半島先端部にある館山湾の南岸，洲 崎の東4.5 kmに位置し, 館山湾を北に望んでいる（図1(a)）．洲崎に至る半島が西向きに大きく伸び，その北岸 に位置するため，当海岸では太平洋からの波は半島によ り遮蔽され, 主に北側の館山湾からの入射波が作用する. 図-1(b)は, 図-1(a)に示古矩形区域の拡大衛星画像を示す。 図に示寸矩形区域が調査対象区域で，見物海岸の東側に は浜田港の防波堤が，また西側には別の舟溜まりが造ら れており，それらにより汀線が固定されている. 見物海 岸の西部は緩やかに凹状の汀線からなる砂浜であるが, 東部では海岸線が逆に緩やかに突出している。この突出 部が調査区域である．図-2にはアメダス館山による2015 年の風配図を示す，見物海岸で出現頻度が最も高い風向 はNNEであり, それにNが続く. 図-1(a)から卓越風向NNE 方向のフェッチを求めると $6.9 \mathrm{~km}$ とる.

\section{3. 現地観測の方法}

図-3 は, 図-1(b)に示す矩形区域の拡大画像であり, 2015 年 10 月 9 日の衛星画像を示す. 公園を防護する護岸の前 面には東部と西部に岩礁が分布している.ここでは便宜 上，東側の岩礁を岩礁 $\mathrm{A}$ ，西側を岩礁 $\mathrm{B}$ と呼ぶ。岩礁 $\mathrm{A}$ は岩礁幅が広く岩礁の陸側端の護岸との接点付近にはほ ぼ半円形状の砂浜を有している。これに比べ，岩礁 B は 沿岸方向に $60 \mathrm{~m}$ の長さを有しているものの, 岩礁 $\mathrm{A} よ$ り規模が小さい.一方，岩礁 A, B 間では沖合から護岸前 面へと深夕が迫る. 図-3には以下の解析で用いた座標系

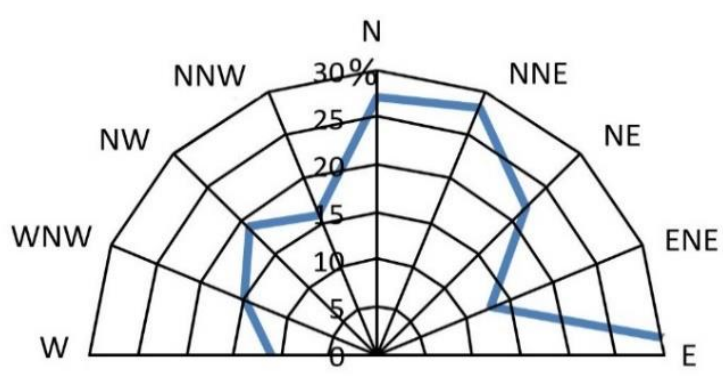

図-2 館山での風向出現頻度分布
を示す，西端に原点を設け，東向きに沿岸方向距離 $X$ を 定めた. また, 図示した No.1〜No.6 の測線では RTK-GPS を用いて 2016 年 8 月 15 日に縦断形測量を行った。また 困に白字で示す 1〜 6 では 2016 年 12 月 15 日に写真撮影 行った. 図-4 には 2016 年の空中写真より判読した汀線 と護岸形状を, 護岸建設前の 1968 年の汀線形状と併せて 示す。これによると 1968～2016 年では岩礁 A の東側区 間では汀線が約 $23 \mathrm{~m}$ 後退している，岩礁 $\mathrm{A}, \mathrm{B}$ 間での汀 線後退量はわずかであるが，現況では汀線は護岸線と重 なっている.

\section{4. 現地状況と縰断形}

海岸状況は，図-3 に番号 1〜6 で示す地点で調べたこ とから, 以下 6 枚の写真で現地状況を示す.まず図-5は， 2016 年 12 月 15 日に撮影した岩礁 A の東側に残された 砂浜背後の St.1 の状況を示す。この付近では護岸前面に 狭い前浜が残されていたが，護岸への越波が著しく，天 端上には多くの漂流物が運び込まれていた.

次に，2016年 8 月 15 日に岩礁 A, B の間の標高 $2.9 \mathrm{~m}$ の護岸上の St.2 から東向きに海岸状況を望んだ写真を図 -6に示す. 前方に見える岩礁 A の背後では, 護岸ののり 先地盤高が高いが，岩礁 $\mathrm{A}$ 上には砂碟が堆積し砂浜が形 成されており，その背後では護岸の天端上に砂碩が堆積 していた．砂浜の位置と護岸上での砂の堆積位置がほぼ

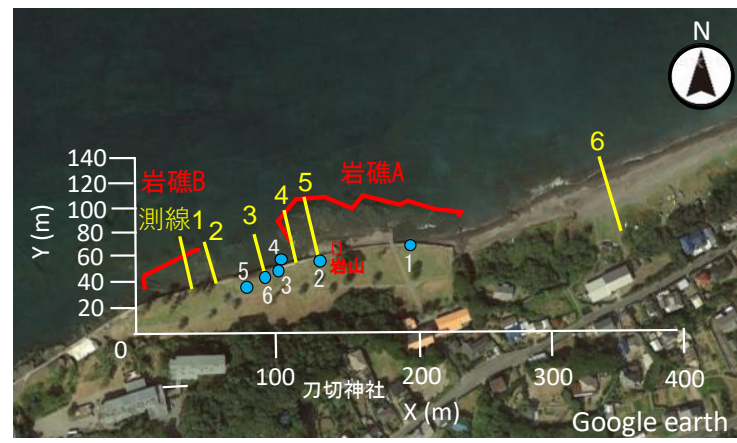

図-3 見物海岸の観測区域

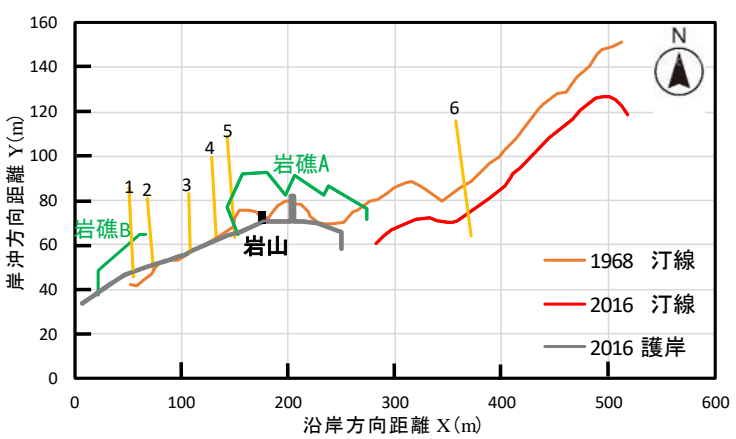

図-4 1968 年と 2016 年の汀線形状の比較 
対応することから，越波時に護岸前面の砂浜から砂碩が 護岸上へ運ばれ堆積したものと考えられる.

次に, 護岸 A を背にして St.3 から西向きに護岸の天端 状況を撮影した写真を図-7 に示寸. 西部の岩礁 B では岩 の密度が東部の岩礁 $\mathrm{A}$ と比べやや低く, またその手前(東) 側には深みが岸近くまで伸びており，そこでは護岸の天 端が黒く変色しているのみでなく, 護岸背後に越波痕跡 が残されていたことから，この深みの背後で越波が著し いことが分かった.

図-8 は2016 年 8 月 15 日の干潮時に，岩礁 A, B 間の 護岸下の St.4で東向きに撮影した護岸基礎の状況を示す。 護岸前面では深みが迫り，そこでは護岸の基礎が黒い帯 状に現れていた.さらに図-8の撮影地点の護岸背後の St.5 では大小複数個の吸出し跡が発見された. 図-9 は St.5 で発見された吸出し穴の 2016 年 8 月 15 日撮影の状況を 示寸.この調査時には, 穴の長径は $2.2 \mathrm{~m}$, 短径が $0.6 \mathrm{~m}$, 深さ $0.4 \mathrm{~m}$ の穴であった. しかし，2016 年 12 月 15 日の 再調査時には穴の長径と短径は夏季と同一であったが, 深さが $0.5 \mathrm{~m}$ と増大していた. 図-8に示したようにこの 付近では護岸の基礎が露出していることから，その付近 で護岸背後の裏込め土砂が吸い出された結果背後地盤の 陷没が起きたと考えられる. また陷没穴の深さが 2016 年 8 月 15 日の $0.4 \mathrm{~m}$ から同年 12 月 15 日の $0.5 \mathrm{~m}$ へと増大

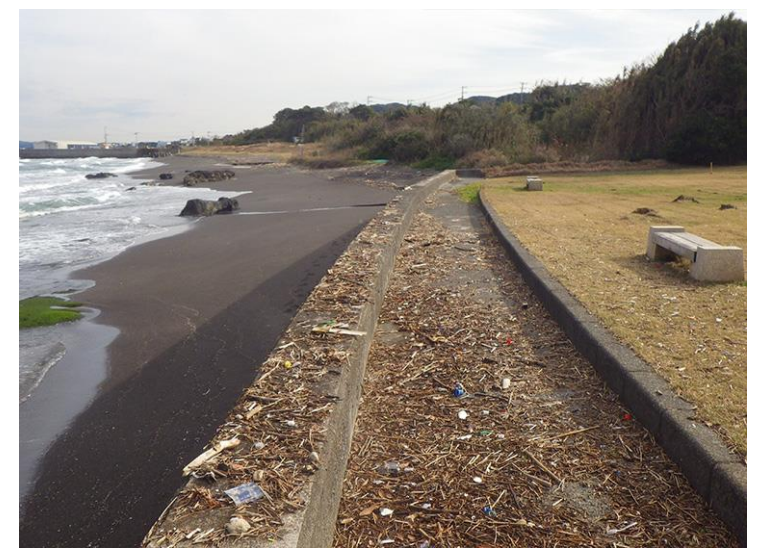

図-5 護岸天端上に残された漂流物（St. 1)

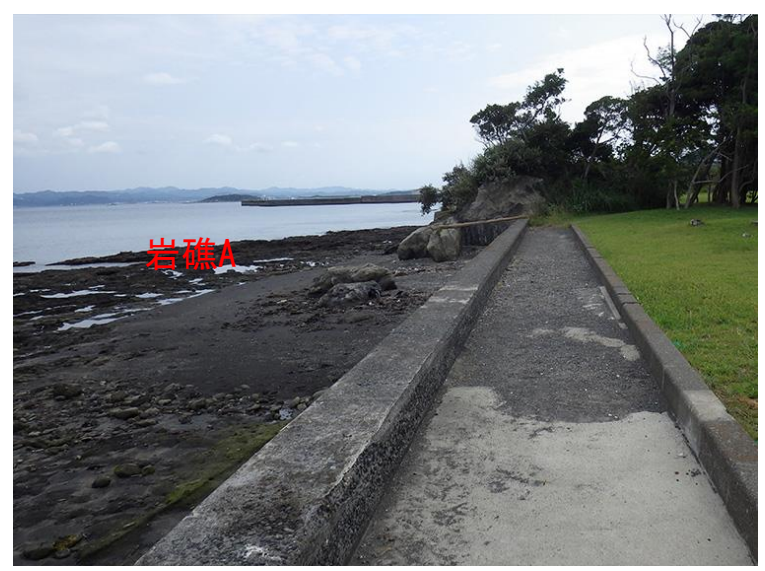

図-6 岩礁Aおよび護岸天端上へ

打ち上げられた砂（St.2）

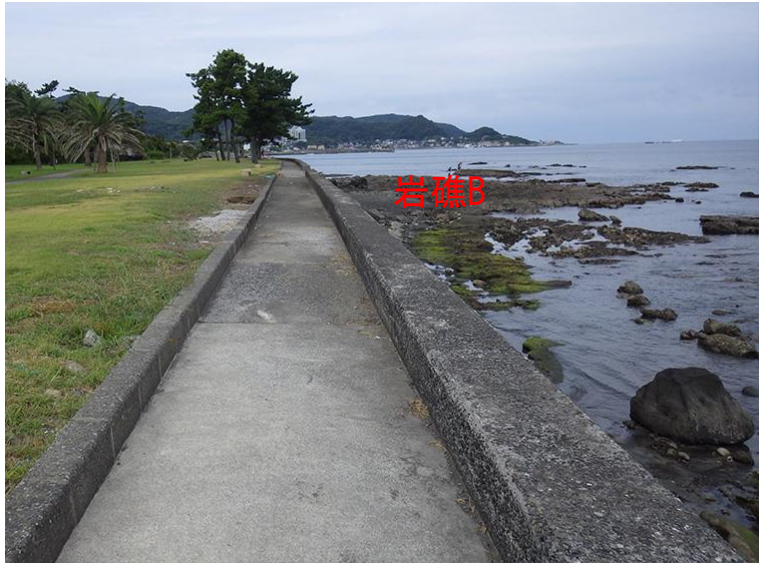

図-7 護岸とその前面に広がる岩礁 B（St. 3）

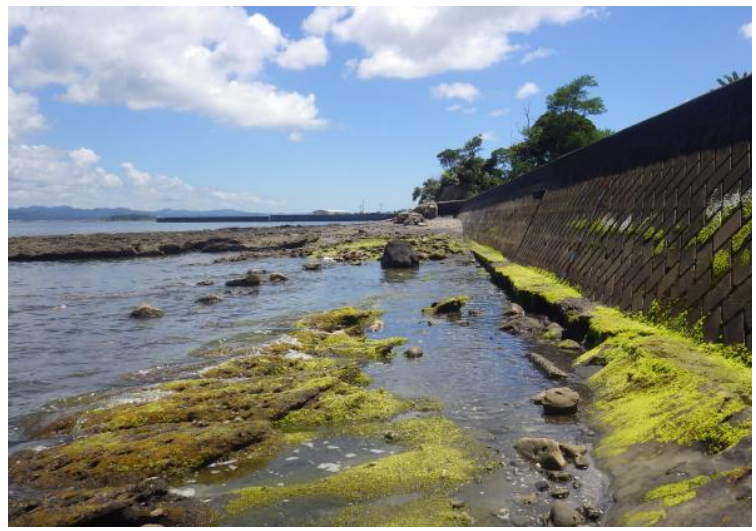

図-8 護岸下部へと迫る深夕（St. 4)

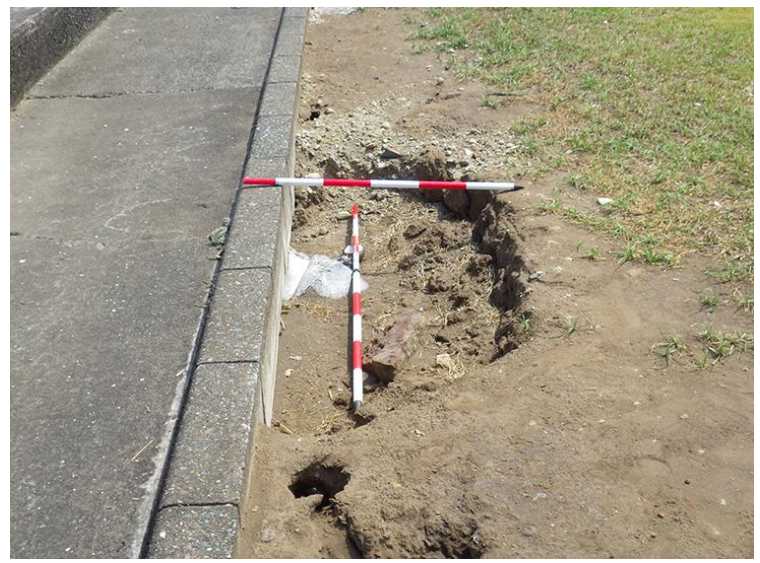

図-9 護岸天端背後に発見された陥没穴（St. 5)

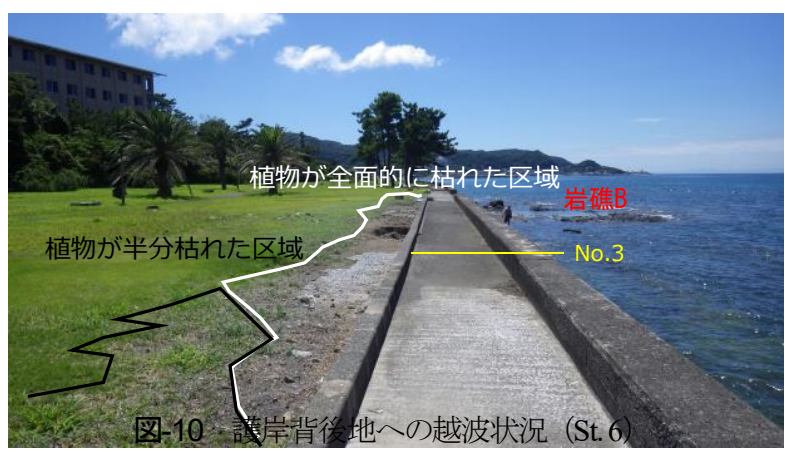


したことから吸い出しは現在もなお続いていることが分 かる. 現況では吸い出しの進行を防ぐために土囊が設置 されてはいたが，穴は完全には塞がれてはいなかった。

最後に, 図-10 は測線 No.3 上のSt.6で撮影した越波状 況写真を示す。この付近では吸出しによる陷没穴，植生 が全面的に枯れた区域，半分枯れた区域が確認でき，陥 没穴の周辺で植生が枯れ，塩害が著しいことが明らかで ある．以上のことから，岩礁帯の有無によって見物海岸 では越波の発生状況が定まっていると考えられる.

図-11 には測線 No.1〜No.5 の縦断形を示す. No.1,No.2 は岩礁帯 B を横断する測線であり, 岩礁 B では水面上の T.P. $0.0 \mathrm{~m} \sim 0.4 \mathrm{~m}$ 間に岩が出ている. No.3 は岩礁間の深 みを横断しており, 護岸前面の水深は $0.3 \mathrm{~m}$ で, その沖 では勾配 1/33 で水深が増加していた. No.4, No.5 は岩礁 A を横断する縦断形である. No.4 上では岩礁の最高標高 は T.P.0.31 m，また No.5 では護岸基部の標高は T.P. $0.8 \mathrm{~m}$ であり, 西部の岩礁 $\mathrm{B}$ と比べ岩礁の高さが高かった.

\section{5. 飛沫観測}

2016 年 12 月 15 日の満潮時，飛沫観測を行った。観 測には水分が付着すると青く変色寸る感水紙を用いた.
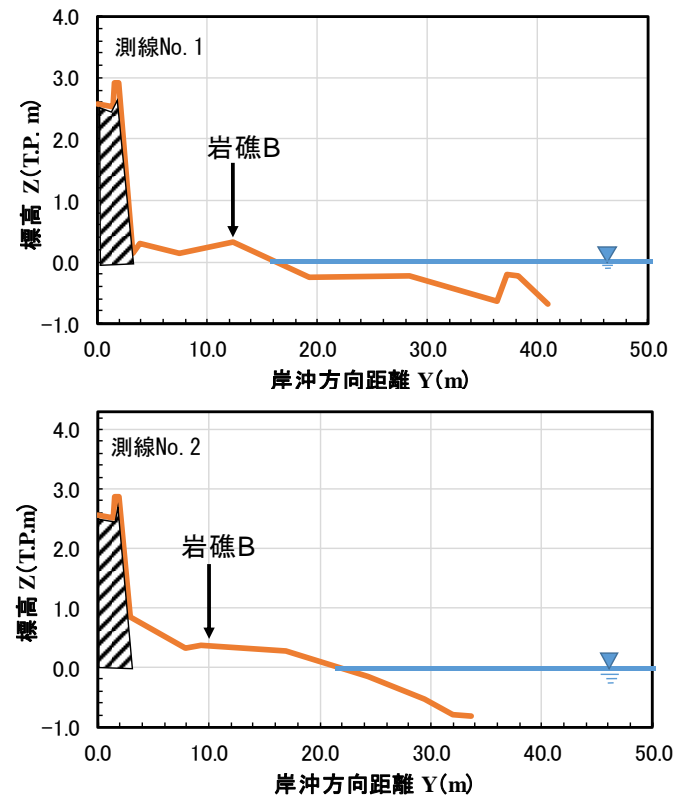

この感水紙は $50 \mu \mathrm{m}$ の液滴まで反応する．感水紙は図12 に示寸ように，護岸背後地の沿岸方向に $23 \mathrm{~m}$, 幅 10 $\mathrm{m}$ のほぼ矩形区域内に, 約 $10 \mathrm{~m}$ 間隔で合計 63 地点配置 した. 感水紙は，図-13に示寸ように地表面上 $0.5 \mathrm{~m}$ とな るよう棒の先に取り付け，地面と垂直でかつ沖向きに設 置した. 観測は 8 人で行い，観測前には感水紙をジップ ロックで覆っておき，観測開始時と同時にジップロック を外し，10 分間観測を行い，観測終了後直ちにジップロ ックを感水紙にかぶせてそれ以上の水滴の付着を防止し た．その後，感水紙を集めて飛沫の面積率を求めた．感 水紙への水分付着状況は青/黄色の面積率により計測し た。図-14 には実例を示す，a は $0.0 \% ， \mathrm{~b}$ は $11.9 \% ， \mathrm{c}$ は $76.1 \%$ の付着状況を示寸. なお, 気象庁が観測した観測時 の館山の風向は NNE，風速は $2.68 \mathrm{~m} / \mathrm{s}$ であった.

図-15 は全 63 地点で観測された感水紙の面積率（\%) を示寸. 飛沫量が高い場所は岩礁 A, B 間の区域の護岸近 傍であり，とくに図の矢印位置では $100 \%$ の飛沫量が観 測された. この付近は図-10に示したように, 護岸背後で の吸出しが起こると同時に越波被害が著しい場所と一致 した. 図-16 には 2015 年 8 月 15 日と 12 月 15 日の測量 結果から補間して求めた深浅図に，飛沫観測結果を重衫 て示した。東部と西部には岩礁 A, B がある一方，中央部 には護岸前面まで深みが迫っている。飛沫の面積率は,
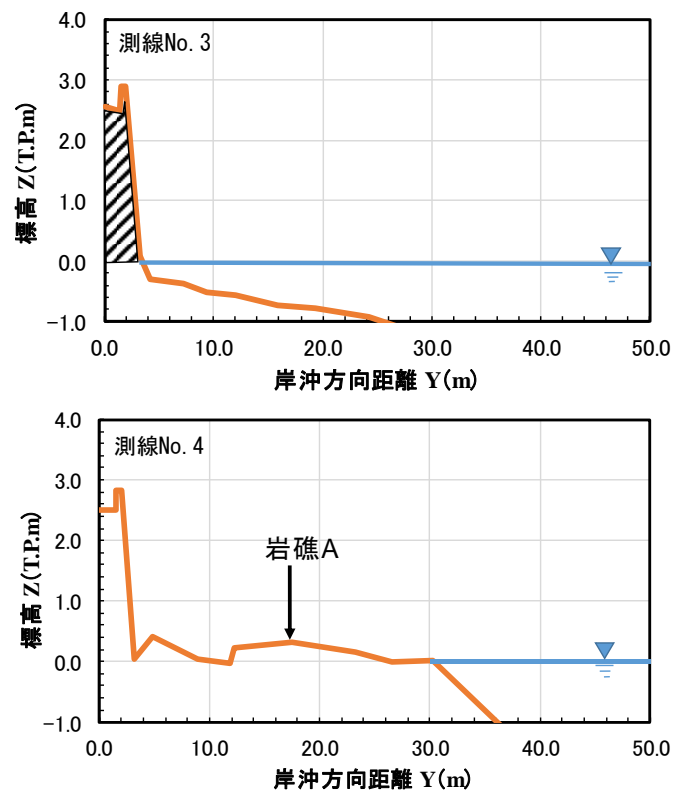

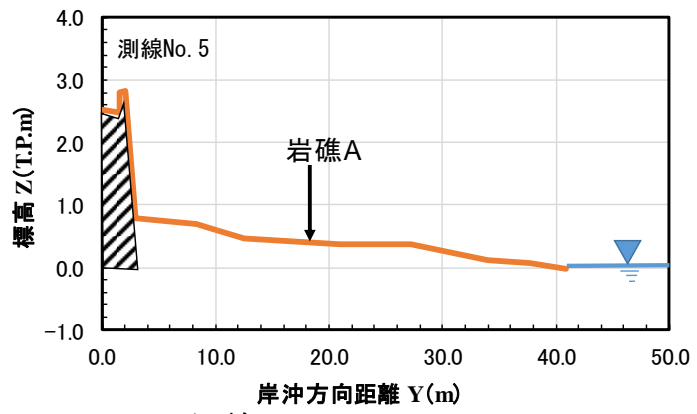

図-11 測線 No.1〜No.5 の縦断形 
$X=80 \mathrm{~m}$ 地点でとくに高く，陸側では飛沫発生量が急減 していた。 その付近は護岸前面の水深が大きい場所と完 全に一致している.

\section{VOF 法による越波計算}

2016 年 12 月 15 日の調査時には，実際に越波の発生が 見られたこと，および現地の状況からも越波被害がある と考えられることから，VOF 法を用いた越波計算を行っ た. 図-16に示したように研究対象区域では中央に深み が迫り，護岸前面の水深が大きいが，その東側と西側に は岩礁があるため水深が小さい，また，当地での卓越風 NNE 方向でありこれらの岩礁または深みを斜めに切る 方向から風波が作用することになる，そこで図-16のよ うにこれらの深みと岩礁を横断する方向に測線 I, II, III を 定め，これらの断面で越波状況の相違について調べた.

図-17 にはこれらの断面形状を示す. 測線 I は岩礁が護岸 前面にあるため他の測線に比べて標高が一番高い. 測線 II は岩礁間の深みを横断する測線のため護岸前面の水深 が大きく，越波が最も著しいと考えられる断面である. また，測線IIIは岩礁と砂浜が混在しているために測線 II

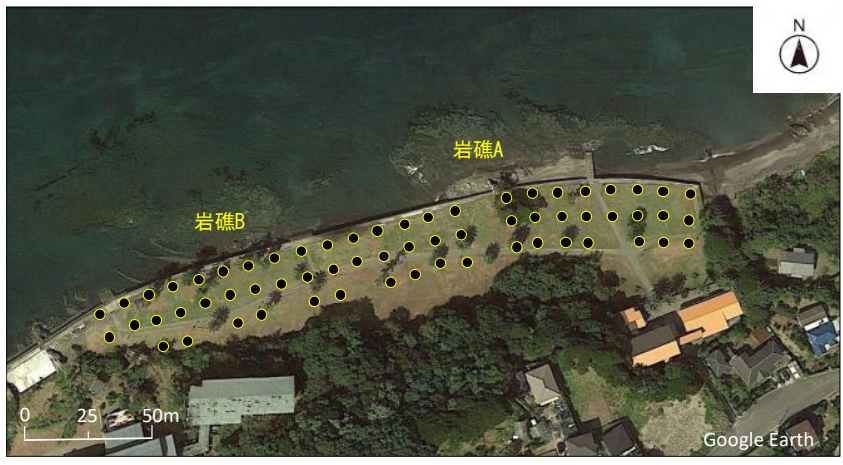

図-12＼cjkstart感水紙の設置地点

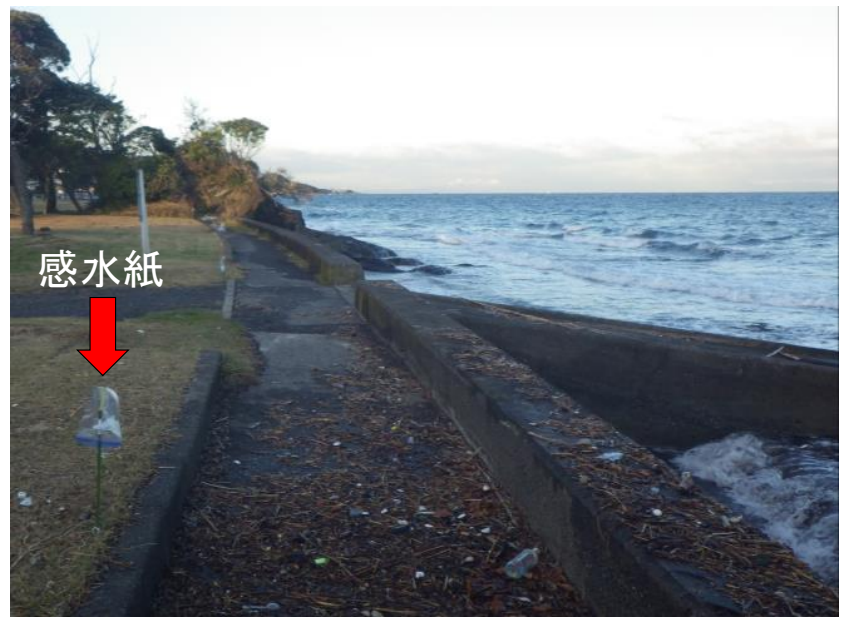

図-13＼cjkstart感水紙の設置方法

と比べると標高が約 $0.5 \mathrm{~m}$ 高い.
計算には CADMAS-SURF ${ }^{1)}$ のプログラムを用い, 今回 は 2 次元計算を行った．当地は館山港に近接しているの で館山港の潮位データを参照すると, HHWL が 1.95 m, HWL が $1 \mathrm{~m}$ である。また，波高は 2015 年のアメダス館 山の風向風速を基に SMB 法により 1 年間の波高を推算 し，上位 $10 \%$ の波高の平均值 $(0.83 \mathrm{~m})$ を用いた.また， 周期は 2017 年 1 月 5 日に現地で撮影した動画から読み 取った值（3.5 s）を用いた。図-18には計算結果を示す. 護岸前面に岩礁の存在する測線 I では，若干の飛沫が上 がるものの越波はしなかった。護岸前面に岩礁のない測 線 II では，護岸の前面水深が最も大きいため波は減衰す ることなく護岸に衝突し，飛沫および越波が起きた。一 方，測線IIIでは越波も飛沫も観測されなかった。

\section{7. まとめ}

見物海岸での観測結果によれば，護岸背後で越波が集 中する場所は護岸前面まで沖合から深夕が迫っている場 所であり，そこではまた護岸背後で降没穴も発見され， そこが海岸管理上の弱点となっていることが明らかにな った。このような弱点箇所では，一般に護岸前面に消波 a

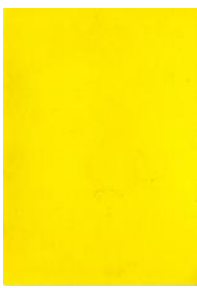

$0.0 \%$ b

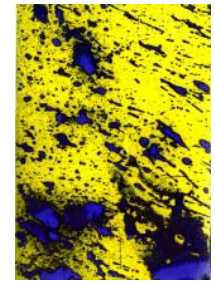

$11.9 \%$
C

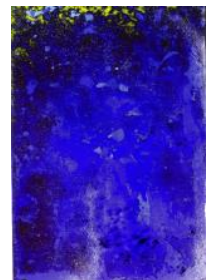

$76.1 \%$
青/黄 飛沫の面積率 $(\%)$

図-14 飛沫試験に用いた感水紙

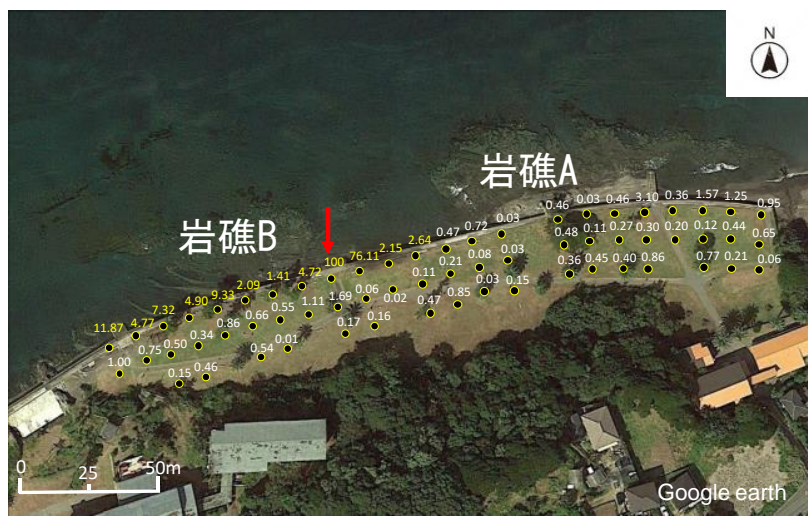

図-15 飛沫面積率の観測結果 


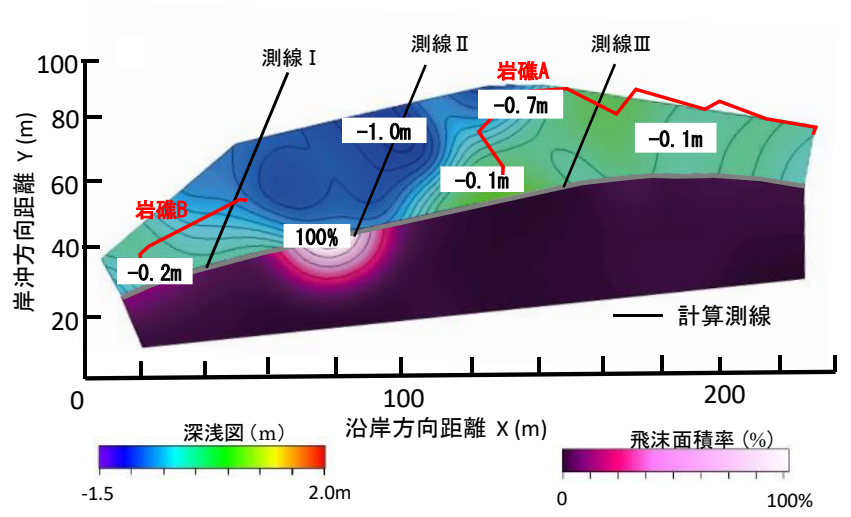

図-16 深浅図と飛沫面積率の分布

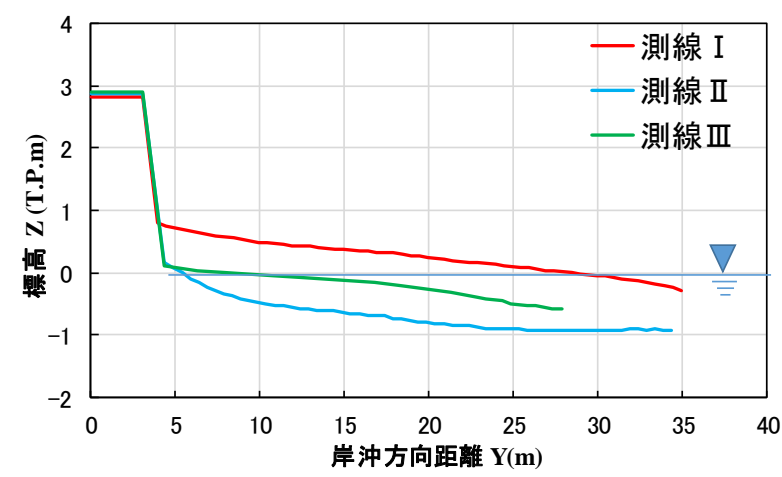

図-17 VOF 法に用いた 3 断面の縦断形

工を並べたり，あるいは沖合に離岸堤や人工リーフが設 置され，この場合自然海岸の風景が損なわれる結果を招 く，しかし現地条件をよく考慮すれば，岩礁に挟まれた 区間の物理条件を無視して護岸が直線状に造られたこと が問題の発端となっていたのであって，防護のために余 分な費用のかかる姿は当初の海岸条件についての理解の 不足が招いたものであることは注意すべきことと考えら れる，なお，本研究で述べた考え方は，海岸保全施設の
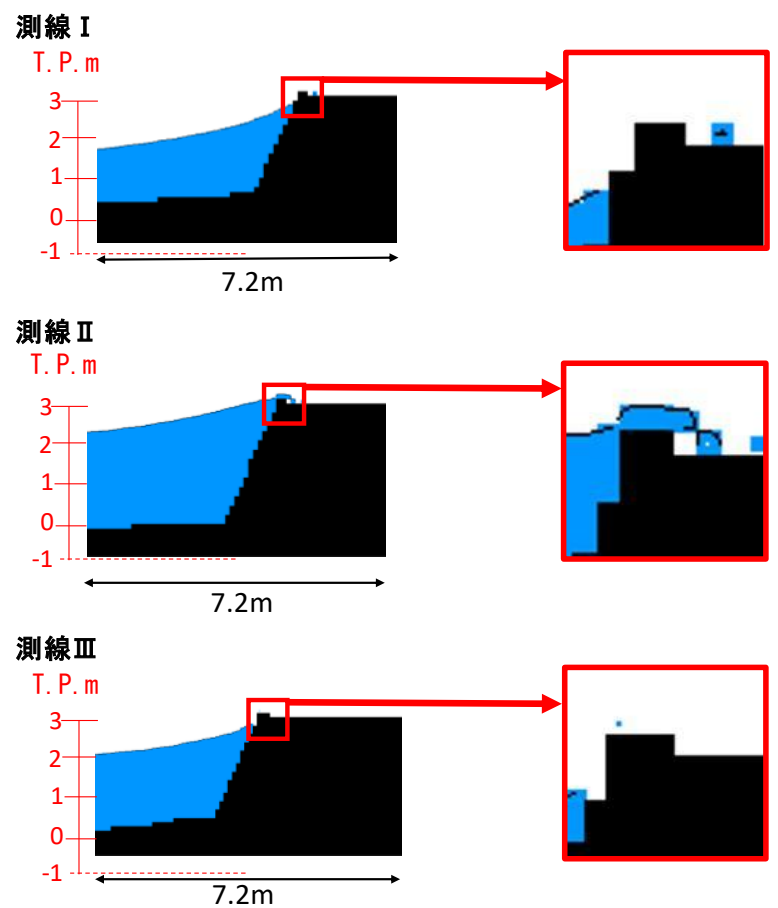

図-18 越波計算の結果 (H.W.L.時)

維持管理マニュアル ${ }^{2)}$ において, 施設の健全性を担保す る上で堤防・護岸の前面の砂浜と施設との関係について 留意することが大事とされる点とも一致している.

\section{参考文献}

1) 財団法人沿岸技術研究センター：CADMAS-SURF/3D 数值波動水槽の研究 - 開発, p.235, 2010 .

2) 海岸保全施設維持管理マニュアル〜堤防・護岸・胸壁 の点検・評価及び長寿命化計画の立案〜:

http://www.mlit.go.jp/kowan/kowan fr7 000014.html

(2017.2.2 受付)

\section{INCREASE IN WAVE OVERTOPPING OVER SEAWALL OF RECLAIMED LAND AND CAVE-IN OF GROUND - AN EXAMPLE OF KENBUTSU COAST -}

\section{Kazuma NISHIMURA, Akio KOBAYASHI, Takaaki UDA and Yasuhito NOSHI}

On April 18, 2015, field observation was carried out on the Kenbutsu coast in front of Katanagiri Shrine, which is located on the south shore of Tateyama Bay. A park was constructed by land reclamation in a shallow sea with reefs and narrow sandy beaches, and a seawall was built in front of the reclaimed land. Near the seawall surrounding the park, the backyard of the seawall was stable at a place with rocky reefs in front, but in an area with a large water depth between the rocks, wave overtopping was severe and sinking of the ground was found. In this study, the seabed topography was measured near the seawall together with the observation of wave overtopping. Then, the wave overtoppoing was calculated by using the VOF method. 